\title{
THE RELATIONSHIP BETWEEN MALAYSIAN PUBLIC-LISTED FIRMS' CORPORATE GOVERNANCE AND THEIR CAPITAL STRUCTURE
}

\author{
Fahed Abdullah Abdlazez *, Alhashmi Aboubaker Lasyoud ${ }^{* * *}$, \\ Abdlmutaleb Boshanna \\ * Faculty of Economics, University of Benghazi, Libya \\ ** Corresponding author, Department of Accounting, College of Business Administration, University of Sharjah, UAE \\ Contact details: Department of Accounting, College of Business Administration, University of Sharjah, P.O. BOX 27272, UAE \\ *** Department of Management, Sobey School of Business, Saint Mary's University, Halifax, Canada
}

\section{OPEN ACCESS}

How to cite this paper: Abdlazez, F. A., Lasyoud, A. A., \& Boshanna, A. (2019). The relationship between Malaysian public-listed firms' corporate governance and their capital structure. Corporate Ownership \& Control, 16(3), 98-112. http://doi.org/10.22495/cocvl6i3art9

\section{Copyright (c) 2019 The Authors}

This work is licensed under a Creative Commons Attribution 4.0 International License (CC BY 4.0).

https://creativecommons.org/licenses/by/ $4.0 /$

ISSN Online: 1810-3057 ISSN Print: 1727-9232

Received: 31.03.2019 Accepted: 22.05.2019

JEL Classification: M41 DOI: $10.22495 /$ cocv 16 i3art9

\begin{abstract}
The purpose of this paper is to investigate the relationship between corporate governance practices and capital structure of public-listed companies in Malaysia. Using the annual reports of 273 Malaysian public-listed firms on the Bursa Malaysia between 2008 and 2012, hierarchical multiple regression analysis was conducted. Corporate governance was measured by variables including board size, CEO duality, ownership structure, and board meeting. Capital structure was measured through four variables: debt-to-equity ratio, long-term debts, short-term debts, and debt ratio. The findings indicated that corporate governance practices have a positive influence on the debt-equity ratio, long-term debt, short-term debt and a debt ratio of capital structure. However, corporate governance practices' influence on the debt ratio is found statistically insignificant. The findings also indicate that firm size moderates the relationship between corporate governance variables and capital structure. Empirically, these findings are useful for measuring and understanding financing decisions taken by the Malaysian public listed firms. It also offers insights to policymakers interested in enhancing the role of corporate governance in formulating management strategies.
\end{abstract}

Keywords: Corporate Governance, Firm Size, Capital Structure, Moderating, Malaysian Public-Listed Companies

\section{INTRODUCTION}

Capital structure refers to a firm's decision to finance its operation and growth using a blend of equity or debts. Thus, it is the different options used by a firm to finance its assets (Bhaduri, 2002). Public-listed firms are profit-oriented entities whose shares are traded on the stock market; thus, they significantly contribute to the country's economic performance (Bryson, Forth, \& Zhou, 2014). The stock market is considered the main source of raising capital and direct investments leading to economic growth. Thus, the capital structures of public-listed firms have a significant influence on the economy of the country where they operate.

During the period between 2008 and 2012, the Malaysian economy experienced significant changes. In 2008, the country witnessed the lowest market capitalization of all the listed companies due to the stock market crash (FMA, 2013). At present, the Malaysian stock market is overvalued, making the market risky for investment. However, appropriate management of capital structure normally enhances corporate performance, which in turn would boost the economic growth in Malaysia. Figure 1 shows the market capitalization of listed companies in Malaysia between 2002 and 2012. 
Figure 1. Market capitalizations of the Malaysian public-listed companies

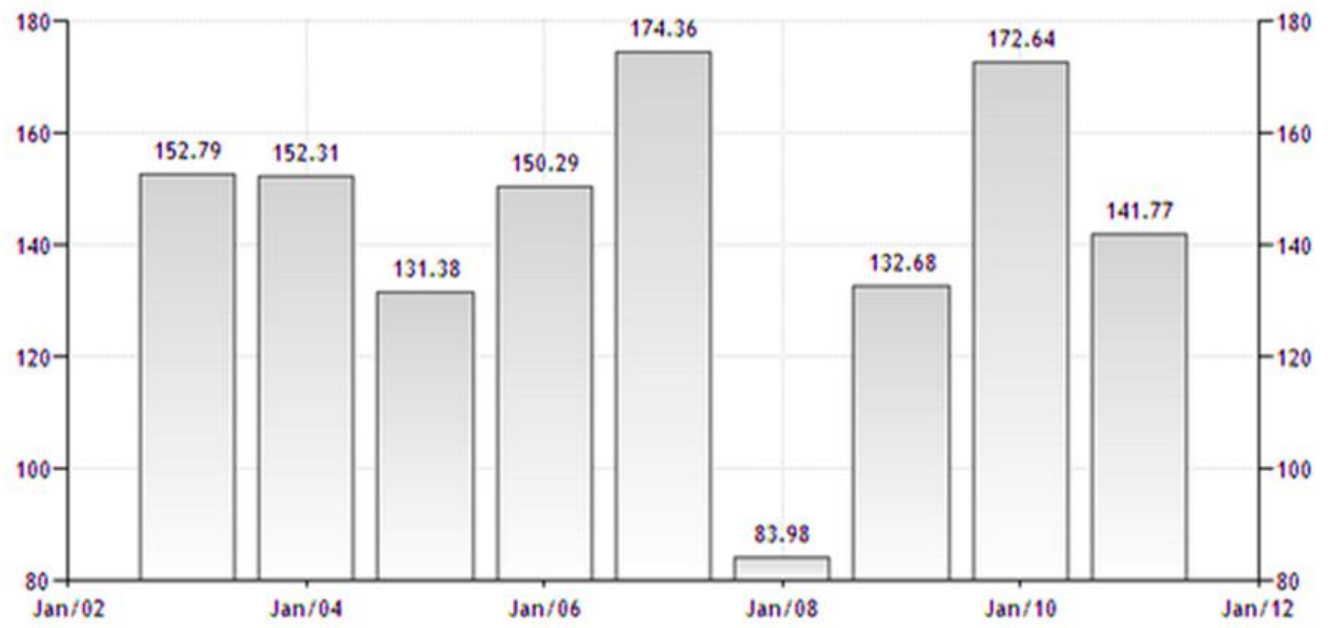

Source: (FMA, 2013)

The topic of debt financing and strategic decisions by companies has attracted comprehensive hypothetical and empirical research (Flannery \& Rangan, 2006; Huang \& Ritter, 2009; Strebulaev, 2007). For example, according to Besley and Brigham (2011), if a firm can produce a return on utilized funds higher than their fixed price, it means that the stockholders' returns are magnified. However, the literature includes some contradictory findings. Specifically, some previous studies found a positive relationship between corporate governance practices and capital structure determinants (Masnoon \& Rauf, 2013; Saad, 2010), whereas other studies found a negative relationship between the same due to entrenched managers and their decisions (Kim, 2011; Wen, Rwegasira, \& Bilderbeek, 2002). Thus, the relationship between corporate governance and capital structure is still not clear and need further investigation.

According to Roslan (2010), between 2003 and 2010, 99 companies were delisted from the official list of Bursa Malaysia because they were embroiled in financial difficulties and financial mismanagement like inefficient, incompetent and wrong distribution of responsibility. The total number of companies delisted in the last decade suggests that the range of delisting of companies is high. Pour and Lasfer (2013) mentioned that the delisted companies come to the market to rebalance their debt rather than to finance their growth opportunities. During their public life, their leverage remains very high (Modugu, 2013). In addition, they cannot raise equity capital, and their profitability, growth opportunities, and trading volume decline substantially. Their stock prices decrease significantly on and before the announcement date. The main reason for the delisting of such companies is poor credit performance and lack of control. This may indicate the importance of having efficient corporate governance practices to control capital structure decision in order to avoid companies' delisting.

According to Modugu (2013), making a decision on capital structure is challenging to firms. Therefore, if managers are to achieve wealth maximization, conscious and timely steps must be taken to identify those factors determining appropriate financing mix (Modugu, 2013). Saad (2010) stated that many studies were conducted on corporate governance and performance, but there is a limited focus on the influence of corporate governance practices on capital structure. In addition, although numerous research studies were performed on the capital structure, understanding in this area is still inconclusive (Myer, 2003). The topic of capital structure has not been prioritized, and no theory was able to encounter the complexity of capital structure independently (Machado, Prado, Vieira, Antonialli, \& Santos, 2015). In addition, Abdelsalam and El-Masry (2008) reported that the available knowledge on firm financing is incomplete and inconclusive. Moreover, Haron (2014) mentioned that corporate financing structure has become more complex especially in developing countries due to market control by institutional constraints. Capital structure is very important as the decision of choosing debt and equity affects the overall financial health of a company.

Hence, in order to ensure work is done ethically with the aim of protecting investors and becoming more transparent to outsiders, there is a need for a monitoring mechanism in the form of corporate governance, which also works as a tool for reducing agency conflict issues. Corporate governance as a monitoring mechanism has been agreed upon in previous research studies (Islam, Islam, Bhattacharjee, \& Islam, 2010). Studies on the relationship between corporate governance and capital structure have focused on several countries such as Korea, Tunisia, India, Bangladesh, the UK, Thailand, and New Zealand. However, only a few studies have been conducted in Malaysia (Lawal, 2012). In order to provide a better understanding of the corporate governance of Malaysian market firms, the main research question for the study is the following: What is the influence of corporate governance practices on the capital structure of the Malaysian public-listed companies? (Will the influence of corporate governance practices 
on capital structure improve corporate performance and shareholder's confidence in such companies?).

The following sub research questions are formulated to guide the study:

- What is the capital structure of Malaysian public-listed companies?

- Does firm size moderates the relationship between corporate governance practices and the firm's capital structure in Malaysian public-listed companies?

The rest of the paper is organized as follows: a literature review presents previous studies related to our topic with a great focus on the capital structure and variables of corporate governance. Then, the theoretical framework explains the theories related to the present study. The methodology applied is also explained followed by findings and conclusions. Finally, the conclusion is stated.

\section{LITERATURE REVIEW}

Corporate governance is the role played by the company's board to maintain and create the company's path and goodwill for shareholders (Forbes \& Milliken, 1999). For the positive performance of a company, leaders and employees play a significant role in applying corporate governance practices (Makhlouf, Laili, Ramli, Al-Sufy, \& Basah, 2018). Gompers, Ishii, and Metrick (2003) asserted that good corporate governance increases valuations and boosts the bottom line. The capital structure of a firm is a specific combination of debt and equity that the firm uses to finance its operations. Therefore, decision-making regarding the capital structure is vital because of the demand to maximize returns to assorted organizational constituencies and to deal with its competitive nature (Abor, 2007).

Kuo, Wang, and Liu, (2012) investigated the influence of corporate governance on capital structure in the context of small and medium enterprises (SMEs) in the Taiwan Stock Exchange and found that large industries prefer to use long-term financing, whereas small industries are more likely to use short-term financing. Another study conducted by Saad (2010) to investigate the influence of corporate governance compliances on the capital structure of industries in Malaysia. Constructs for corporate governance were dual leadership, board size and board meeting explaining debt to equity, debt ratio and interest coverage of capital structure. The result found a positive relationship between corporate governance and firm's capital structure. Furthermore, some studies revealed that board dynamics like size, CEO duality and diversity are amongst factors increasing firm performance (Lawal, 2012; Darko, Aribi, Uzonwanne, Eweje, \& Eweje, 2016). In addition, Qadorah and Fadzil (2018) concluded that CEO duality contributes significantly to firm performance.

Hussainey and Aljifri (2012) studied the relationship between corporate governance practices and capital structure in the UAE, where attributes of corporate governance were highly related to explaining the capital structure. Firm size was found to be highly significant and positively influential in the capital structure. Sheikh and Wang (2012) also empirically studied the influence of corporate governance on the capital structure of firms in Pakistan. Attributes of corporate governance like board size, outside directors, ownership concentration, managerial ownership director remuneration, CEO duality were utilized, whereas, for capital structure, total debt ratio and long-term debt were used. Managerial ownership was found to have a negative influence on the capital structure, whereas CEO duality was not significant to explain capital structure (Sheikh \& Wang, 2012). Ehikioya (2009) used board size, risk, inside ownership, foreign ownership, board independence and CEO quality as attributes for corporate governance practices and long-term debt over equity, leverage, debt ratio, tax asset tangibility, dividend yield, and Profitability were used as attributes for capital structure. The finding showed that board size significantly influences capital structure choices.

Omran and Pointon (2009) investigated the capital structure and firm characteristics through variables such as liquidity, asset structure, growth, size, fiscal characteristics, corporate tax rates, stock market activity for corporate governance and variables like debt level, short-term financing for capital structure. Masnoon and Rauf (2013) investigated the impact of corporate governance on capital structure and revealed that board composition, CEO duality and ownership concentration have a negative influence on the debt ratio. Similarly, another study performed by Alagathurai (2013) mentioned that corporate governance practices are significant in reducing the risk for investors. The study found a mixed relationship between corporate governance and capital structure.

Therefore, it can be confirmed that there is a significant body of hypothetical and empirical research in accounting and finance that considers the relations between corporate governance, agency incomings, corporate capital structure, and corporate ownership structure. Hence, from an econometric viewpoint, to discover the relationship between each two of these variables, one should devise an arrangement of simultaneous equations that specify the relationships between these variables.

\subsection{Board size and capital structure}

The board of directors plays a crucial role in the corporate governance of companies. In fact, there is a strong relationship between board size and capital structure (Pfeffer \& Salancik, 2003). However, the evidence on the types of relationship between the board size and capital structure is mixed. Berger et al. (1997) found that firms with a large board of Directors (BOD) generally have low gearing ratios. Moreover, large boards exert pressure on managers to maintain low gearing ratios and to enhance firm performance. Generally, the board of directors is responsible for the firm operation. Pfeffer and Salancik (2003) confirmed that a large board size translates into forceful pressure on managers to improve firm performance. In addition, research indicates a positive relationship between the board size and the organization influence through capital structure because boards that are extra entrenched pursue a higher influence to raise the firm value (Abor, 2007). Furthermore, Anderson, Mansi, and Reeb (2004) found that the price of debt is usually lower for larger boards because lenders believe that these firms are being monitored carefully by a 
diversified portfolio of experts; thus, debt financing becomes a price competent choice. On the other hand, Abor (2007) scrutinized the relationship between corporate governance and the capital of Ghanaian Small and Medium Enterprises by employing multivariate regression analysis. The outcome indicated a negative relationship between the board size and influence ratios meaning that SMEs with larger boards usually have a low level of gearing. Ehikioya (2009) mentioned that previous studies like (Berger et al., 1997; Wen et al., 2002) found a significant relationship between the board size and capital structure indicating that large board size is associated with a higher debt level. Abor (2007) found a high correlation between capital structure and board size.

It is also argued that a large board size leads to larger corporate governance because of the skills, vision, and expertise held into boardroom discussion. However, Chin, Vos, and Casey (2004) did not find a significant relationship between board size and capital structure. Some studies suggested that a large board size could lead to difficulties in cluster coordination and in reaching a consensus on capital structure decisions (Jensen, 1993). This idea is upheld by Conyon and Peck (1998) who discovered a negative relationship between board size and corporate governance across a number of European countries. Additionally, Eisenberg, Sundgren, and Wells (1998) found a negative correlation between board size and profitability in small Finnish corporations. On the other hand, researchers like Wen et al. (2002) provide facts indicating a negative relationship between gearing level and re-governance of non-official managers on the board. The probable reason is that non-official managers monitor the managers more effectively and efficiently so managers are compelled to pursue lower gearing levels to accomplish superior results. Comparably, firms with higher re-governance of non-official managers are likely to pursue low organization influence with an inflated marketplace worth of equity (Wen et al., 2002).

\subsection{CEO duality and capital structure}

Corporate governance has been recognized by preceding studies as influential in the capital structure of firms (Berger et al., 1997; Bergstresser \& Philippon, 2006; Friend \& Lang, 1988). These studies explained the main characteristics of corporate governance as board size, board constitution, CEO duality, the tenure of the CEO and CEO compensation. However, empirical findings on the relationship between corporate governance and capital structure are varied and inconclusive. According to Fama and Jensen (1983), decision control and decision management should be separate entities. On the other hand, Fosberg (2004) argued that in the absence of CEO duality, the management uses an optimum level of debt in their capital structure. They also highlighted that there is a negative but insignificant relation between a high level of debt and leverage. These results are also supported by Abor and Biekpe (2007) who found a positive but insignificant relationship between CEO duality and leverage. According to Abdullah (2004), the majority of the companies listed in Malaysia's KLCI main board are dominated by outside directors and have non-dual leadership structures.
The relationship between CEO duality and capital structure management is controversial. There are strong sentiments amongst boards to separate the position of the CEO and the board chairperson. However, the stewardship theory states that corporations benefit from CEO duality due to unified leadership. Thus, it is important to examine the influence of CEO duality on the capital structure of the firms. The presence of a CEO/Chair duality signals the nonexistence of separation of decision making and decision control, which in the end leads to agency problems. Fosberg (2004) mentioned that firms with a distinct chairperson and CEO retain the optimal number of debt in their capital structures. He discovered that firms with a distinct CEO and chairperson usually have higher organization leverage. Abor (2007) additionally provided facts indicating a positive relationship between financial leverage and CEO duality.

\subsection{Ownership structure and capital structure}

Ownership has many forms including manager ownership, external ownership, and power ownership. Manager ownership, as stated by Jensen and Meckling (1976), can aid in alleviating agency fights between managers and owners. That is because a manager who owns a great sum of the firm shares has extra incentives to maximize job governance for efficient performance. However, Chiang and Chia (2005) observed that manager shareholding was statistically significant but negatively connected to corporate performance. Also, Bokpin and Arko (2009) reported a positive relationship between ownership and capital structure.

External ownership is when a great sum of the firm's shares is owned by external stockholders. It indicates that external stockholders have assurance in those companies, which in turn could lead to a higher valuation of the corporate. Furthermore, Bai, Liu, Lu, Song, and Zhang (2004) described that providing shares to external financiers has positive results on marketplace valuation. Prior studies additionally documented that firms with a higher proportion of external stockholders revealed considerably extra data in their annual reports (Haniffa \& Cooke, 2002). Brailsford and Yeoh (2002) suggest that the relationship between managerial share ownership and leverage may, in fact, be nonlinear. At a low level of managerial ownership, agency conflicts fall leading to higher debt and capital structure. However, when managers already hold a significant portion of firms' equity, an increase in managerial ownership may lead to an increase in managerial opportunism and therefore may cause lower debt.

Short, Keasey and Duxbury (2002) examined the influence of ownership structure on the organization structure of UK firms and found that there is a positive relationship between agency ownership and influence ratio, whereas a negative relationship is noted between large external equity holder's ownership and organization leverage. However, the relationship between agency ownership and influence ratio is not significant with the presence of beyond equity holders. These findings suggest that beyond equity holders affect the agency prices of equity financing and debt financing. La Rocca (2007) investigated the 
relationship between internal resource finance, shareholder ownership, cash flow allocation, debt and equity, where the capital structure was found to be an important instrument for the corporate governance efficiency and firm value. Abdelsalam and El-Masry (2008) investigated the influence of board independence and ownership structure on the timeliness of internet reporting and profitability of the company. After controlling the size, audit fees and firm performance, there is evidence that timeliness is positively associated with the board of director's independence and CEO ownership. Jensen and Meckling (1976) argue that managerial shareownership may reduce managerial incentives to consume perquisites, to expropriate shareholders' wealth and to engage in other non-maximizing behaviour; thus, it helps in aligning the interests of management with those of the shareholders.

Butt and Hasan (2009) while investigating the relationship between ownership structure and corporate governance in the capital structure of Pakistan listed companies found that board size and managerial shareholding have a negative correlation with debt to equity ratio. The result revealed that size, ownership and managerial shareholding play a crucial role in the financial mix determination of the firms. However, according to Javeed, Hassan, and Azeem (2014), capital structure positively impacts the firm value, and in case of corporate governance, board independence and ownership concentration were found to enhance the firm value. In addition, governance measures were found to have no effect on the leverage of the firm. However, Jiraporn, Kim, and Davidson (2008) investigated the influence of multiple directorships on corporate diversification and found that when board members hold more outside board seats high diversification discount takes place. Furthermore, Ajanthan, Balaputhiran, and Nimalathashan (2013) examined the relationship between corporate governance and business performance using board size, board diversity, ownership concentration, and the frequency of board meeting as dimensions of corporate governance in relation to return on equity and return on assets for business performance. The study found that all the variables have a positive relationship with return on equity except board diversity and board meeting which have a negative relationship.

Government ownership is another public feature of the Malaysian corporate environment. The government's involvement in the corporate sector is chiefly evident in privatized entities. One of the specific aims of privatization is to rearrange and safeguard an extra equitable society. As of December 2000, privatized entities constituted 5 percent of tabulated companies; nonetheless, they gave 30.3 percent to finish marketplace capitalization. Power ownership in privatized entities as of that date was 49.5 percent. Given the significance of privatized entities, it could be anticipated that the power should be closely monitored and overseen. The government should safeguard the accomplishment of these firms so that the goals of privatization are met. Empirical facts on the relationship between government ownership and corporate governance are mixed. Hovey, Li, and Naughton, (2003) evidenced that state ownership did not have explanatory control on corporate performance. Firms that wage dividends have extra committees. Firms with higher CEO ownership have fewer group purposes given by the board. On the other hand, firms with larger boards, extra assets, and extra board meetings have extra group functions. In supplement, dividend-paying firms have extra group functions. In addition, firms with higher CEO ownership allocate fewer tasks to every single committee.

Previous studies have attempted to explain how corporate ownership influences corporate decisionmaking concerning the relationship between corporate capital structure and ownership (Ang \& Ding, 2006; Coleman, 2002; Friend \& Lang, 1988; Holderness, 2009). Theoretically, the way the funds are controlled and utilized also influences the method of financing real investment. The percentage of ownership by the shareholders as per the total assets of the firm is taken into considerations. Thus, this research also focuses on the percentage of shares owned by the shareholders in order to investigate the ownership structure of the firm.

\subsection{Board meeting and capital structure}

A firm with a large board and numerous board meetings have more functions to perform. It is the responsibility of the management to monitor such board meetings to make sure they work for the growth of the firm. Boone, Casares, Field, Karpoff, and Raheja, (2007) stated that board size and board composition are determined by firm-specific factors and managerial works. The inner monitoring role is not exclusive to the board of managers; corporate governance indicates that this role includes other mechanisms. For example, audit committees perform inner control mechanisms in order to efficiently monitor firms' audit practices. This suggests that audit groups can reduce data asymmetry between associates and outsiders (Saad, 2010). Vafeas (2000) examined the relationship between board meetings and the company value in 307 firms tabulated in the Forbes 1992 for the period between 1990 and 1994 and found that the number of board meetings held each year was negatively related to the company value. The role of the board of managers is to provide consultation to the manager and to prevent the excessive consumption of assets.

Adams, Almeida, and Ferreira, (2005) stated that the extent of monitoring considerably increases if the firm's governance declines. Vafeas (2000) used the number of board meetings as an indication of board monitoring and found that firms suffering from poor governance increase the number of board meetings, which enhances their governance in future years. Boone, et al. (2007) found empirical evidence on the effect of monitoring of the board. Furthermore, some studies additionally found that as the number of autonomous managers in a board increases, the incidence of corporate fraud decreases (Dechow, Sloan, \& Sweeney, 1996; Klein, Shapiro, \& Young, 2005; Sharma, 2004; Uzun, Szewczyk, \& Varma, 2004).

Studies like Denis and Sarin (1999) and Sundaram and Yermack (2007) posited that the level of monitoring is positively related to the number of autonomous managers on the board. Firms with higher CEO ownership have fewer group functions. Firms with larger boards and extra group meetings have extra group functions. Larger firms and 
dividend-paying firms additionally have extra group functions. Firms that have a human resource group have lower governance measured by market-to-book ratio than those without. A recent study performed by Wahba (2015) to investigate the board characteristics enhancing a firm performance revealed that board independence, board meetings, and board expertise have a significant impact on the capital structure and firm performance.

Capital structure is negatively related to the percentage of shares owned by corporate managers, but it has a positive relationship with the percentage of shares owned by the managers assisting the finance and investment group and the strategy committee. Also, studies stated that capital structure is negatively related to the percentage of the shares owned by the CEOs.

\subsection{Firm size as moderating variable}

Empirical studies on corporate finance consider firm size a moderate variable; thus, it receives slight attention in most research papers. Generally, findings indicate that large firms in the US are inclined to have higher leverage ratios than small firms (Shumway, 2001). Globally, most, if not all, assets are influenced by firm size (Booth, Aivazian, Demirguc-Kunt, \& Maksimovic, 2002). Many authors affirmed the relation between debt ratio and firm size. In addition, Bodaghi and Ahmadpour (2010) empirically explained the relation between corporate governance and capital structure and suggested that ownership structure and firm size play an important role in the determination of capital structure. Gruber and Warner (2012) suggested that moderately large firms incline to be extra diversified and less prone to bankruptcy. These arguments indicate that large firms are more leveraged. The price of delivering debt and equity assurances is additionally connected with the firm size. In particular, small firms pay more for new equity compared with large firms. Alternatively, size influences the probability of default because larger firms are tougher to flounder and to liquidate (Shumway, 2001). In addition, size may moderate the volatility of firm assets because small firms are more inclined to be manufacturing firms operating in growing and unpredictable industries.

In today's corporate world, the size of firms, capital structure, and earnings management are very important. Burgstahler and Dichev (1997) studied 300 companies to examine how the earnings are managed and found that both small and large sized firms use earnings management to avoid a decrease in earnings. Rangan (1998) identified a positive relationship between earnings management and governance of experienced equity offerings. Nelson, Elliott, and Tarpley (2002) made a survey for 253 experienced auditors asking them to recognize how earnings were truly grasped from their point of view. The survey displayed that from time to time auditors could flout the earnings management of large-sized firms. Furthermore, Vo and Phan (2013) investigated the influence of corporate governance on firm's performance with firm size as a moderating variable. Kim, Liu, and Rhee (2003) examined the relationship between corporate earnings management and firm size. They analyzed the earnings of small, medium and large firms in relation to their size and the marketplace worth of every single year based on an example data of 18 years. They noted that the firm size had a significant effect on earnings management. On one hand, small sized firms avoided the supplement of earnings management. On the other hand, the medium and large size firms were extra encompassed in earnings management. Bergstresser and Philippon (2006) discovered that CEO compensation has a positive relationship with the tendency of firms to increase earnings.

Moreover, Quayyoum and Zoltan (2015) conducted a regression analysis to determine the impact of leverage on return on equity while considering the firm size to be moderating this relationship and found that the firm size is highly significant. Furthermore, Abbasi and Malik (2015) also examined the effect of firm size as a moderating factor in the relationship between firm growth and firm performance. The regression analysis they conducted demonstrated that the firm size has a moderating effect on the relationship between firm growth and firm performance. Thus, this study also investigates the moderating influence of the firm size in the relationship between corporate governance and capital structure.

Drawing upon the above discussion and arguments regarding corporate governance practices and the firm's capital structure, the following main hypotheses are designed:

H1: There is a significant influence of corporate governance practices on capital structure in Malaysian public listed companies.

H2: There is a moderating influence of firm size on the relationship between corporate governance practices and the firm's capital structure.

\section{THEORETICAL FRAMEWORK}

The literature review provides a framework for understanding the relationship between corporate governance and capital structure controlled by firm size as shown in the below Figure 2 . It also covers the decision of managers regarding their debt-equity financing. The literature indicates that effective corporate governance practices lead to an effective decision making role regarding debt-equity financing in the public listed companies in Malaysia. On one hand, some previous studies found a positive relationship between corporate governance and capital structure determinants (Masnoon \& Rauf, 2013; Erwan, Nikolov, \& Schürhoff, 2008; Saad, 2010). On the other hand, studies such as Friend and Lang (1988), Kim (2011), and Wen et al., (2002) found a negative association between corporate governance and capital structure due to entrenched managers and their decisions. Thus, the relationship between corporate governance and capital structure is still not clear and needs further investigation. The determinants of corporate governance practices and capital structure are shown below in the research model formulated in Figure 2. 
Figure 2. Theoretical framework

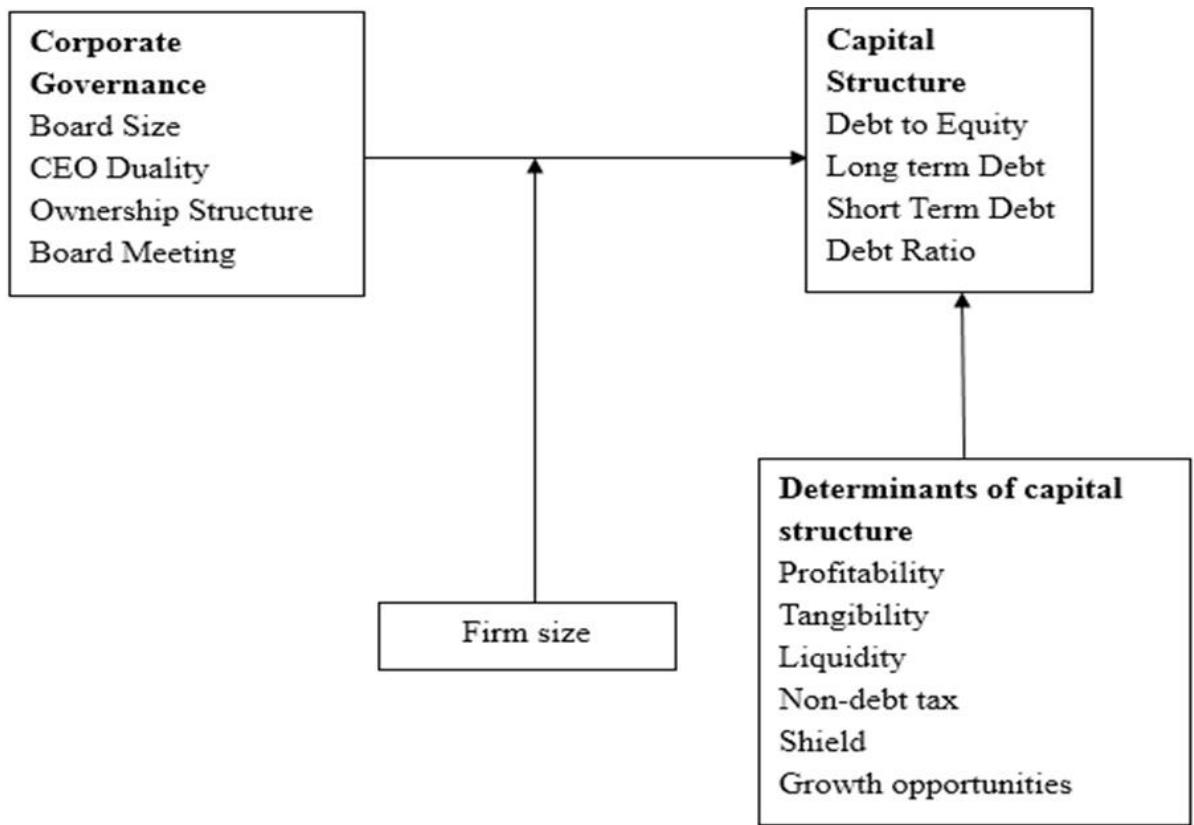

\section{METHODOLOGY}

\subsection{Sample and data collection}

The study is based on secondary data analysis. Historical information of public listed Malaysian firms, their financial reports, and narrative reports were used for the calculations of corporate governance practices and capital structure. Historical data of the listed companies have been collected from Bursa Malaysia Stock Exchange website and from the "Library" of Bursa Malaysia website. The annual reports that were not available on the website were requested from the companies by email. Some data were also collected from Thomson Reuter database. Malaysia was chosen as the place for the study as it is a huge emerging market and is characterized by economic liberalization through international trade and commerce.

The study was conducted for the period between 2008 and 2012 because the researchers were interested to identify the fluctuation of the influence of corporate governance on the capital structure during and after the global financial crisis that was experienced by Malaysian companies in 2008/2009. The study covers the listed companies (main market) in Bursa Malaysia. The firms in the population were selected based on the following criteria using the appropriate selection and application of weights that are necessary for the accuracy or generalizability estimates as illustrated in Table 1 below:

- The main market listed companies which have been listed on Bursa Malaysia in or before June 2013.

- They must have existed in Bursa Malaysia until the financial year 2012.

- They should not have negative values for average operating income during the period of the study as the negative result may affect the overall purpose of the study (Savita, 2012).

In order to maintain the consistency in the data, companies listed or established after 2008 were excluded. In addition, finance, real estate, and hotel sectors were excluded due to having different corporate governance practices and limited availability of financial data. Previous studies excluded financial companies from their investigation because of the peculiarity of their operations and capital structure (Amer, Caroline, Rosle, Rahimie, and Lim, 2013). In fact, the majority of studies investigating capital structure exclude financial sectors to ensure the validity of the assumptions (Dionne, 2013). Thus, only 822 companies were considered the population of the study. From the population of 822 , a minimum of 260 - 265 sample size was collected. After the data screening process, a total of 273 companies was selected for further analysis.

Table 1. Total number of population

\begin{tabular}{|l|c|c|c|c|c|}
\hline \multicolumn{1}{|c|}{ Industries type } & $\mathbf{2 0 0 8}$ & $\mathbf{2 0 0 9}$ & $\mathbf{2 0 1 0}$ & $\mathbf{2 0 1 1}$ & $\mathbf{2 0 1 2}$ \\
\hline Construction & 42 & 43 & 50 & 47 & 19 \\
\hline Consumer products & 131 & 146 & 153 & 45 \\
\hline Industrial products & 277 & 275 & 283 & 258 \\
\hline Plantation & 46 & 45 & 44 & 42 \\
\hline Properties & 96 & 100 & 97 & 91 \\
\hline Technology & 32 & 35 & 35 & 30 \\
\hline Trading/services & 191 & 229 & 212 & 49 \\
\hline Total of population & 815 & 873 & 874 & 187 \\
\hline
\end{tabular}




\subsection{Variables and measurements}

Based on the in-depth literature review performed in Section 2, variables like board size, CEO duality, ownership structure, and board meeting were included to explain corporate governance practices; whereas, variables including debt to equity ratio, debt to asset ratio, long-term debt, short-term debt were included to measure a firm's capital structure. The following subsections discuss in detail each related variables of this research:

\subsubsection{Board size}

The board size is defined as the group of people comprising the governing body of the corporation (Guest, 2009). Corporate boards play a central role in the corporate governance of companies. The two basic functions of the board of directors are advising and monitoring (Raheja \& Charu, 2005). In this study, the number of board members on the board of directors is considered as the board size.

\subsubsection{CEO duality}

The current study focuses on CEO duality, where a person holds both positions of chief executive officer and chairperson of the board (Nazir, Aslam, \& Nawaz, 2012). In this study, the names of the CEO and the chairpersons were compared, and if they were the same then CEO duality were considered present. According to the agency theory, the CEO duality negatively influences the firm's capital structure due to the strong authority and decisionmaking power especially in the financial decision (Masnoon \& Rauf, 2013). However, the Stewardship theory supports the duality based on the unity of the command and better and quick decision-making. When a person has both designations of CEO and chairperson, the greater control of CEO may enhance the level of debt. So, a positive relationship can be expected between CEO duality and firms' leverage.

\subsubsection{Ownership structure}

The ownership structure is measured in terms of foreign (outside) ownership and managerial (inside) ownership. Researchers have investigated ownership structure using different approaches. Sulong and Nor (2008) examined ownership structure by considering the total percentage of shares owned by the largest five shareholders. In addition, Driffield, Mahambare, and Pal (2007) investigated the influence of ownership structure on the capital structure using the distribution of ownership amongst the top five shareholders. Nonetheless, studies such as Chen, Firth, and Xu (2009) and Kirchmaier and Grant (2005) have considered the top three shareholders in order to confirm whether the company has foreign or inside ownership. Furthermore, after reviewing the annual reports of the public listed companies in Malaysia, it was revealed that the majority of the ownership was owned by the top three shareholders. Thus, this study utilizes the three largest shareholders to determine the ownership structure of the firms in order to make the information more reliable. If external block-holders serve as active monitors, management may not be able to adjust debt to their own interests as freely if such investors do not exist. In this sense, firms with higher external blockholding are likely to have a higher debt ratio. This is because large debt increases the risks of bankruptcy.

\subsubsection{Board meeting}

The board meeting is defined as the number of meetings held by the board members in a financial year. Board meetings are held so members of a board of directors can make decisions regarding the direction of a company. The meeting includes a report on the company's financial performance, a report by the management on the operations of the company for the period since the last board meeting, details of any round robin resolution passed since the last board meeting for notice purpose, and particulars of resolutions that the board will be asked to consider together with supporting documentation. The board meeting is calculated as the annual number of board meetings held in the company.

\subsubsection{Debt to Equity ratio}

The Debt-Equity ratio indicates the relative contribution of the total debt and owner's equity to the capital structure of the company; the relative contribution of each to finance the company's assets (Chen \& Chen, 2011). It is computed as in (1):

$$
\text { Debt to Equity = Debt } / \text { Equity }
$$

\subsubsection{Long-term debts}

"Any loan of financial obligations of the company that is more than one year of the time period, such obligation is considered as long-term debt on the balance sheet of the firm" (Kisgen, 2006, p.4). For example, the company's issued bonds or long-term leases and the bank loan and financial agreements that have a maturity greater than one year are considered a long-term debt as in (2):

$$
\text { Long term debt }=\frac{\text { Long term debt } \times \text { total asset }}{\text { Total asset }}
$$

\subsubsection{Short-term debts}

"Any loan of financial obligations of the company that is less than one year of the time period, such obligation is considered as short-term debt on the balance sheet of the firm" (Kisgen, 2006, p.7) as shown in (3):

$$
\text { Short term debt }=\frac{\text { Short term debt } \times \text { total asset }}{\text { Total asset }}
$$

\subsubsection{Debt ratio}

The more a firm borrows, the riskier its outstanding stock and bonds are, and the higher the return that investors require on those securities. There are two types of debt ratios. One type focuses on balance sheet measures of outstanding debt relative to other sources of financing. The other type, known as coverage ratio, focuses more on income statement measures of the firm's ability to generate sufficient cash flow to make scheduled interest and principal 
payments. Investors and credit rating agencies use both types of debt ratio to assess the firm's creditworthiness (Graham, Harvey, \& Rajgopal, 2005). The debt ratio measures the proportion of total assets financed by the firm's creditors. The ratio equals total liabilities divided by total assets as shown in (4):
Debt ratio $=$ Total liabilities $/$ Total assets

(4)

\subsubsection{Determinants of capital structure}

The measurements of determinants of the capital structure are shown in the below Table 2 .

Table 2. Determinants of capital structure

\begin{tabular}{|c|l|l|}
\hline No. & \multicolumn{1}{|c|}{ Variable } & \multicolumn{1}{c|}{ Indicator } \\
\hline 1 & Profitability (PROF) & Return on Assets: EBIT/Total Assets \\
\hline 2 & Asset Tangibility (TANG) & Fixed Assets/Total Assets \\
\hline 3 & Growth/Growth Opportunities (GRO) & The growth of Total Assets (\%) \\
\hline 4 & Non-Debt Tax Shield (NDTS) & Depreciation/Total Assets \\
\hline 5 & Liquidity (LIQ) & $\begin{array}{l}\text { Quick Ratio: (Current Assets - Inventories)/Total Assets Current Ratio: } \\
\text { Current Asset/Current Liabilities }\end{array}$ \\
\hline
\end{tabular}

\subsubsection{Firm size as a moderating variable}

Moderation occurs when the relationship between two variables depends on a third variable, which is referred to as the moderator variable or simply the moderator (Kenny, 2015). In this study, the firm size was hypothesized to moderate the relationship between capital structure and corporate governance. Firm size is calculated as the asset value of the firms (Shumway, 2001). Asset value is the net market value of the company's asset divided by the number of outstanding shares.

\subsection{Hierarchical multiple regression}

This hierarchical regression examines the influence of corporate governance variables including board size, CEO duality, board meeting, ownership structure and control variables including profitability, tangibility, liquidity, non-debt tax shield and growth opportunities as well as firm size as a moderating variable on debt-equity ratio, longterm debts, short-term debt, and debt ration of capital structure as dependent variables. The equations (5), (6), (7), and (8) show the regression equation between the constructs.

$$
\begin{gathered}
D E=\alpha+\beta 1 B S i+\beta 2 D U i+\beta 3 B M i+\beta 4 O S i+\beta 5(B S * D U * B M * O S * F S)+\beta 6(B S F S * D U F S \\
* B M F S * \text { OSFS })+\varepsilon \\
\text { LTD }=\alpha+\beta 1 B S i+\beta 2 D U i+\beta 3 B M i+\beta 4 O S i+\beta 5(B S * D U * B M * O S * F S)+\beta 6(B S F S * D U F S \\
* B M F S * O S F S)+\varepsilon \\
\text { STD }=\alpha+\beta 1 B S i+\beta 2 D U i+\beta 3 B M i+\beta 4 O S i+\beta 5(B S * D U * B M * O S * F S)+\beta 6(B S F S * D U F S \\
* B M F S * O S F S)+\varepsilon \\
D R=\alpha+\beta 1 B S i+\beta 2 D U i+\beta 3 B M i+\beta 4 O S i+\beta 5(B S * D U * B M * O S * F S)+\beta 6(B S F S * D U F S \\
\quad B M F S * O S F S)+\varepsilon
\end{gathered}
$$

Where,

$\mathrm{DE}=$ Debt equity ratio; LTD = Long-term debts; $\mathrm{STD}=$ Short-term debts; $\mathrm{DR}=$ Debt ration; $\alpha=$ Model's Intercept constant; $\beta 1-4=$ Regression coefficient associated with corporate governance variables 1 to 4 ; $\mathrm{BS}=$ Board size; $\mathrm{DU}=\mathrm{CEO}$ duality; $\mathrm{BM}=$ Board meeting; OS = Ownership structure; PROF = Profitability; TANG = Tangibility; LIQ =
Liquidity; ND = Non-debt shield; FS = Firm size; $\varepsilon=$ Residual term.

\begin{tabular}{|c|c|c|c|c|}
\hline \multirow{2}{*}{ Variables } & \multicolumn{4}{|c|}{ Beta standardized } \\
\hline & Model 1 & Model 2 & Model 3 & Model 4 \\
\hline \multicolumn{5}{|l|}{ Control variables } \\
\hline Profitability & .106 & .088 & .094 & .096 \\
\hline Tangibility & .053 & .076 & .081 & .086 \\
\hline Liquidity & -.039 & -0.43 & -.046 & -.044 \\
\hline Non-debt Tax Shield & -.096 & -.101 & -.098 & -.098 \\
\hline Growth opportunity & -.085 & -.074 & -.070 & -.061 \\
\hline \multicolumn{5}{|l|}{ Independent variables } \\
\hline Board size & & .091 & .101 & .117 \\
\hline CEO duality & & $.249^{* * *}$ & $.252^{* * *}$ & $.314^{* * *}$ \\
\hline Board meeting & & -.045 & -.032 & -.045 \\
\hline Ownership structure & & .000 & .004 & .000 \\
\hline \multicolumn{5}{|l|}{ Moderating variable } \\
\hline Firm size & & & -.051 & .142 \\
\hline
\end{tabular}

Tables 3, 4, 5, and 6 show the hierarchical regression results of firm size as moderator on the influence of corporate governance practices on debt to equity ratio, long-term debts, short-term debts, and debt ratio, respectively.

Table 3. Hierarchical regression results of firm size as a moderator on the influence of corporate governance practices on debt to equity ratio (Part 1) 
Table 3. Hierarchical regression results of firm size as a moderator on the influence of corporate governance practices on debt to equity ratio (Part 2)

\begin{tabular}{|c|c|c|c|c|}
\hline \multirow{2}{*}{ Variables } & \multicolumn{4}{|c|}{ Beta standardized } \\
\hline & Model 1 & Model 2 & Model 3 & Model 4 \\
\hline \multicolumn{5}{|l|}{ Interaction } \\
\hline IV1*M1 & & & & -.276 \\
\hline IV2*M1 & & & & $-.143^{*}$ \\
\hline IV3*M1 & & & & .114 \\
\hline IV4*M1 & & & & .009 \\
\hline $\mathrm{R}^{2}$ & .020 & .087 & .089 & .106 \\
\hline Adj R ${ }^{2}$ & .002 & .056 & .055 & .058 \\
\hline $\mathrm{R}^{2}$ change & .020 & .067 & .002 & .017 \\
\hline F change & 1.098 & 4.825 & .615 & 1.212 \\
\hline Durbin-Watson & \multicolumn{4}{|l|}{1.976} \\
\hline
\end{tabular}

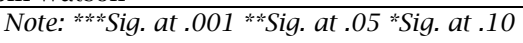

Table 4. Hierarchical regression results of firm size as a moderator on the influence of corporate governance practices on long-term debt

\begin{tabular}{|c|c|c|c|c|}
\hline \multirow{2}{*}{ Variables } & \multicolumn{4}{|c|}{ Beta standardized } \\
\hline & Model 1 & Model 2 & Model 3 & Model 4 \\
\hline \multicolumn{5}{|l|}{ Control variables } \\
\hline Profitability & .019 & $\begin{array}{l}.027 \\
\end{array}$ & -.059 & .000 \\
\hline Tangibility & $.175^{* *}$ & $.158^{* *}$ & $.100 * *$ & .048 \\
\hline Liquidity & -.020 & -.014 & .025 & .007 \\
\hline Non-debt Tax Shield & .032 & -.002 & -.038 & -.058 \\
\hline Growth opportunity & .066 & .049 & .003 & .004 \\
\hline \multicolumn{5}{|l|}{ Independent variables } \\
\hline Board size & & $.200^{* * *}$ & .077 & $-.074^{*}$ \\
\hline CEO duality & & .101 & .052 & -.035 \\
\hline Board meeting & & .234 & .065 & .016 \\
\hline Ownership structure & & $.129 * *$ & .078 & -.050 \\
\hline \multicolumn{5}{|l|}{ Moderating variable } \\
\hline Firm size & & & $.660^{* * *}$ & $-1.198^{* * *}$ \\
\hline \multicolumn{5}{|l|}{ Interaction } \\
\hline IV1*M1 & & & & $1.746^{* * *}$ \\
\hline $\mathrm{IV} 2 * \mathrm{M} 1$ & & & & $.252^{* * *}$ \\
\hline IV3*M1 & & & & -.188 \\
\hline IV4*M1 & & & & $.435^{* * *}$ \\
\hline $\mathrm{R}^{2}$ & .040 & .166 & .526 & $.736^{*}$ \\
\hline Adj R ${ }^{2}$ & .022 & .137 & .508 & .721 \\
\hline $\mathrm{R}^{2}$ change & .040 & .125 & .360 & .210 \\
\hline F change & 2.243 & 9.885 & 199.135 & 51.189 \\
\hline Durbin-Watson & \multicolumn{4}{|l|}{1.776} \\
\hline
\end{tabular}

Note: $* *$ Sig. at .001**Sig. at .05*Sig. at .10

Table 5. Hierarchical regression results of firm size as a moderator on the influence of corporate governance practices on short-term debt

\begin{tabular}{|c|c|c|c|c|}
\hline \multirow{2}{*}{ Variables } & \multicolumn{4}{|c|}{ Beta standardized } \\
\hline & Model 1 & Model 2 & Model 3 & Model 4 \\
\hline \multicolumn{5}{|l|}{ Control variables } \\
\hline Profitability & .000 & -.016 & -.085 & -.039 \\
\hline Tangibility & .099 & .091 & .044 & .036 \\
\hline Liquidity & -.095 & -.099 & -.068 & -.042 \\
\hline Non-debt Tax Shield & -.027 & -.057 & -.086 & $-.095^{* *}$ \\
\hline Growth opportunity & .072 & .052 & .016 & .036 \\
\hline \multicolumn{5}{|l|}{ Independent variables } \\
\hline Board size & & $.227^{* * *}$ & $.128^{* *}$ & -.071 \\
\hline CEO duality & & .096 & .057 & .024 \\
\hline Board meeting & & .078 & -.057 & .070 \\
\hline Ownership structure & & $.152^{* *}$ & .112 & -.074 \\
\hline \multicolumn{5}{|l|}{ Moderating variable } \\
\hline Firm size & & & $.528^{* * *}$ & $-.739 * * *$ \\
\hline \multicolumn{5}{|l|}{ Interaction } \\
\hline IV1*M1 & & & & $2.138^{* * *}$ \\
\hline IV2*M1 & & & & $.135 * * *$ \\
\hline IV3*M1 & & & & $-1.512^{* * *}$ \\
\hline IV4*M1 & & & & $.728 * * *$ \\
\hline $\mathrm{R}^{2}$ & .027 & .115 & .346 & .682 \\
\hline $\operatorname{Adj~R} R^{2}$ & .009 & .084 & .321 & .665 \\
\hline $\mathrm{R}^{2}$ change & .027 & .088 & .231 & .336 \\
\hline F change & 1.485 & 6.512 & 92.467 & 68.285 \\
\hline Durbin-Watson & \multicolumn{4}{|l|}{1.698} \\
\hline
\end{tabular}

Note: ${ }^{* * *}$ Sig. at $.001 * *$ Sig. at $.05 *$ Sig. at .10 
Table 6. Hierarchical regression results of firm size as a moderator on the influence of corporate governance practices on the debt ratio

\begin{tabular}{|c|c|c|c|c|}
\hline \multirow{2}{*}{ Variables } & \multicolumn{4}{|c|}{ Beta standardized } \\
\hline & Model 1 & Model 2 & Model 3 & Model 4 \\
\hline \multicolumn{5}{|l|}{ Control variables } \\
\hline Profitability & -.033 & .001 & .010 & .005 \\
\hline Tangibility & .012 & .007 & .014 & .019 \\
\hline Liquidity & -.001 & .007 & .003 & .004 \\
\hline Non-debt Tax Shield & .087 & .076 & .080 & .082 \\
\hline Growth opportunity & .067 & .074 & .079 & .080 \\
\hline \multicolumn{5}{|l|}{ Independent variables } \\
\hline Board size & & -.106 & -.092 & -.101 \\
\hline CEO duality & & .010 & .015 & .022 \\
\hline Board meeting & & $.175^{* *}$ & $.194^{* *}$ & $.206^{* *}$ \\
\hline Ownership structure & & .014 & .020 & .037 \\
\hline \multicolumn{5}{|l|}{ Moderating variable } \\
\hline Firm size & & & -.075 & -.135 \\
\hline \multicolumn{5}{|l|}{ Interaction } \\
\hline IV1*M1 & & & & .182 \\
\hline IV2*M1 & & & & -.019 \\
\hline IV3*M1 & & & & -.064 \\
\hline IV4*M1 & & & & -.082 \\
\hline $\mathrm{R}^{2}$ & .011 & .048 & .053 & .056 \\
\hline $\operatorname{Adj~} R^{2}$ & -.008 & .016 & .017 & .005 \\
\hline $\mathrm{R}^{2}$ change & .011 & .038 & .005 & .003 \\
\hline F change & .578 & 2.607 & 1.303 & .199 \\
\hline Durbin-Watson & \multicolumn{4}{|l|}{1.969} \\
\hline
\end{tabular}

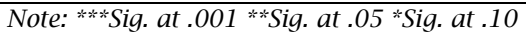

\section{FINDINGS AND DISCUSSION}

The main objective of this study was to investigate the influence of corporate governance variables (board size, CEO duality, board meeting and ownership structure) on capital structure (debt to equity, long-term debt, short-term debt, and debt ratio) and interaction variables like profitability, tangibility, liquidity, non-debt tax shield and growth opportunities, and to identify the role of firm size as moderating the relationship between corporate governance practices and capital structure of Malaysian firms. The empirical results indicated that corporate governance has a positive effect on capital structure with firm size as a moderating variable and control variables including profitability, tangibility, liquidity, non-debt tax shield, and growth opportunities; thus, $H 1$ and $H 2$ are supported. These results are similar to findings of other studies. For example, Bodaghi and Ahmadpour (2010) studied the relationship between corporate governance and capital structure and indicated that firm size plays an important role in determining the capital structure. Similarly, Agyei and Owusu (2014) investigated the relationship between ownership structure and corporate governance in listed manufacturing companies in Ghana Stock Exchange between 2007 and 2011. They concluded that firm size has a positive significant effect on capital structure. In addition, Rehman, Rehman, and Raoof (2010) examined the relationship between corporate governance and capital structure of randomly selected 19 banks of Pakistan for the period between 2005 and 2006. They concluded that board size and capital structure are positively related.

The details of the effects of firm size on the relationship between corporate governance and capital structure variables are below.

First, there is a low moderating influence of firm size on the relationship between corporate governance variables and debt to equity ratio. Second, firm size has a very high moderating influence on the relationship between corporate governance variables and long-term debt. Third, firm size has a very high influence on the relationship between corporate governance variables and shortterm debts. Finally, firm size is found to have a very low influence on the relationship between corporate governance variables and debt ratio. Significantly, the empirical findings in this study showed that using less debt would produce increased and better performance.

\section{CONCLUSION}

This study attempted to examine the influence of corporate governance on capital structure among public-listed companies in Malaysia. Hierarchical multiple regression analysis was conducted for the annual reports of 273 Malaysian public-listed firms on the main board of Bursa Malaysia between 2008 and 2012. Variables of corporate governance were measured including board size, CEO duality, ownership structure, and board meeting. In addition, the capital structure was examined by measuring four variables: debt-to-equity ratio, long-term debts, short-term debts, and debt ratio.

The findings indicated that corporate governance practices have a positive influence on the debt-equity ratio, long-term debt, short-term debt and a debt ratio of capital structure. However, corporate governance practices' influence on the debt ratio is not statistically significant. Moreover, the firm size was found to moderate the relationship between corporate governance variables and capital structure. Accordingly, it can be concluded that corporate governance practices affect the efficient utilization of the firm's resources.

In spite of the different techniques applied in this study to ensure the robustness and accuracy of the findings, some limitations still exist. First, the sample contains data of five years only. Second, the study examines only four corporate governance constructs, while there are many other corporate governance constructs such as external corporate governance that would have an important impact on 
capital structure. Furthermore, focusing on the quantitative data while ignoring the qualitative data may be considered a limitation because qualitative analysis would have indicated actual issues faced at the moment by the business entities.

The findings in this study indicated low $\mathrm{R}^{2}$ between the variables, which is a reason for conducting future research on the same topic.
Because test variables and control variables were many in number, the study could not include supporting variables like board composition, managerial ownership, managerial incentives of corporate governance practices and tax shield benefits, profitability, tangible assets of capital structure which can be included in future research to gain in-depth research study.

\section{REFERENCES}

1. Abbasi, A., \& Malik, Q. A. (2015). Firms' size moderating financial performance in growing firms: An empirical evidence from Pakistan. International Journal of Economics and Financial Issues, 5(2), 334-339. Retrieved from https://www.econjournals.com/index.php/ijefi/article/view/1074

2. Abdelsalam, O.H., \& El-Masry, A. (2008). The impact of board independence and ownership structure on the timeliness of corporate internet reporting of Irish-listed companies. Managerial Finance, 34(12), 907-918. https://doi.org/10.1108/03074350810915842

3. Abdullah, S. (2004). Board composition, CEO duality, and performance among Malaysian listed companies. Corporate Governance: The International Journal of Business in Society, 4(4), 47-61. https://doi.org/10.1108/14720700410558871

4. Abor, J., \& Biekpe, N. (2007). Corporate governance, ownership structure and performance of SMEs in Ghana: Implications for financing opportunities. Corporate Governance: The International Journal of Business in Society, 7(3), 288-300. https://doi.org/10.1108/14720700710756562

5. Abor, J. (2007). Corporate governance and financing decisions of Ghanaian listed firms. Corporate Governance: The International Journal of Business in Society, 7(1), 83-92. https://doi.org/10.1108/14720700710727131

6. Adams, R. B., Almeida, H., \& Ferreira, D. (2005). Powerful CEOs and their impact on corporate performance. The Review of Financial Studies, 18(4), 1403-1432. https://doi.org/10.1093/rfs/hhi030

7. Agyei, A., \& Owusu, A. R. (2014). The effect of ownership structure and corporate governance on capital structure of Ghanaian listed manufacturing companies. International Journal of Academic Research in Accounting, Finance and Management Sciences, 4(1), 109-118. https://doi.org/10.6007/IJARAFMS/v4-il/547

8. Ajanthan, A., Balaputhiran, S., \& Nimalathashan, B. (2013). Corporate governance and banking performance: A comparative study between private and state banking sector in Sri Lanka. European Journal of Business and Management, 5(20), 92-100. Retrieved from https://www.iiste.org/Journals/index.php/EJBM/article/view/7303

9. Alagathurai, A. (2013). Impact of corporate governance practices on firm capital structure and profitability: A study of selected hotels and restaurant companies in Sri Lanka. Research Journal of Finance and Accounting, 4(10). Retrieved from https://papers.ssrn.com/sol3/papers.cfm?abstract_id=2381183

10. Amer, A., Caroline, G., Rosle, M., Rahimie, A., \& Lim, S. (2013). Capital structure decisions: Evidence from large capitalized companies in Malaysia. Interdisciplinary Journal of Contemporary Research in Business, 5(5), 30-49. Retrieved from https://www.researchgate.net/publication/257880594_Capital_Structure_Decisions_Evidence_ from_Large_Capitalized_Companies_in_Malaysia

11. Anderson, R. C., Mansi, S. A., \& Reeb, D. M. (2004). Board characteristics, accounting report integrity, and the cost of debt. Journal of Accounting and Economics, 37(3), 315-342. https://doi.org/10.1016/ j.jacceco.2004.01.004

12. Ang, J. S., \& Ding, D. K. (2006). Government ownership and the performance of government-linked companies: The case of Singapore. Journal of Multinational Financial Management, $16(1), 64-88$. https://doi.org/10.1016/j.mulfin.2005.04.010

13. Bai, C.-E., Liu, O., Lu, J., Song, F. M., \& Zhang, J. (2004). Corporate governance and market valuation in China. Journal of Comparative Economics, 32(4), 599-616. https://doi.org/10.1016/j.jce.2004.07.002

14. Berger, P. G., Ofek, E., \& Yermack, D. L. (1997). Managerial entrenchment and capital structure decisions. The journal of finance, 52(4), 1411-1438. https://doi.org/10.1111/j.1540-6261.1997.tb01115.x

15. Bergstresser, D., \& Philippon, T. (2006). CEO incentives and earnings management. Journal of Financial Economics, 80(3), 511-529. https://doi.org/10.1016/j.jfineco.2004.10.011

16. Besley, S., \& Brigham, E. (2011). Principles of finance $\left(5^{\text {th }}\right.$ ed.). USA: Cengage Learning. Retrieved from https://www.amazon.com/Principles-Finance-Scott-Besley/dp/1111527369

17. Bhaduri, S. N. (2002). Determinants of capital structure choice: A study of the Indian corporate sector. Applied Financial Economics, 12(9), 655-665. https://doi.org/10.1080/09603100010017705

18. Bodaghi, A., \& Ahmadpour, A. (2010). The effect of corporate governance and ownership structure on capital structure of Iranian listed companies. Paper presented at the 7th International Conference on Enterprise Systems, Accounting and Logistics.

19. Bokpin, G. A., \& Arko, A. C. (2009). Ownership structure, corporate governance and capital structure decisions of firms: Empirical evidence from Ghana. Studies in Economics and Finance, 26(4), 246-256. https://doi.org/10.1108/10867370910995708

20. Boone, A. L., Casares Field, L., Karpoff, J. M., \& Raheja, C. G. (2007). The determinants of corporate board size and composition: An empirical analysis. Journal of Financial Economics, 85(1), 66-101. https://doi.org/10.1016/ j.jfineco.2006.05.004

21. Booth, L., Aivazian, V., Demirguc-Kunt, A., \& Maksimovic, V. (2002). Capital structures in developing countries. The Journal of Finance, 56(1), 87-130. https://doi.org/10.1111/0022-1082.00320

22. Brailsford, T. J., \& Yeoh, D. (2004). Agency problems and capital expenditure announcements. The Journal of Business, 77(2), 223-256. https://doi.org/10.1086/381274

23. Bryson, A., Forth, J., \& Zhou, M. (2014). Through the looking glass: CEO pay in China's listed companies. Research-based Policy Analysis. Retrieved from https://voxeu.org/article/through-looking-glass-ceo-pay-chinaslisted-companies

24. Burgstahler, D., \& Dichev, I. (1997). Earnings management to avoid earnings decreases and losses. Journal of Accounting and Economics, 24(1), 99-126. https://doi.org/10.1016/S0165-4101(97)00017-7 
25. Butt, S., \& Hasan, A. (2009). Impact of ownership structure and corporate governance on the capital structure of Pakistani listed companies. International Journal of Business and Management, 4(2), 50-57. https://doi.org/10.5539/ijbm.v4n2p50

26. Chen, G., Firth, M., \& Xu, L. (2009). Does the type of ownership control matter? Evidence from China's listed companies. Journal of Banking and Finance, 33(1), 171-181. https://doi.org/10.1016/j.jbankfin.2007.12.023

27. Chen, L.-J., \& Chen, S.-Y. (2011). The influence of profitability on firm value with the capital structure as the mediator and firm size and industry as moderators. Investment Management and Financial Innovations, 8(3), 121-129. Retrieved from https://businessperspectives.org/images/pdf/applications/publishing/templates/ article/assets/4210/imfi_en_2011_03_Chen.pdf

28. Chiang, H.-t., \& Chia, F. (2005). An empirical study of corporate governance and corporate performance. Journal of American Academy of Business, 6(1), 95-101.

29. Chin, T., Vos, E., \& Casey, Q. (2004). Levels of ownership structure, board composition and board size seem unimportant in New Zealand. Corporate Ownership and Control, 2(1), 119-128. https://doi.org/ $10.22495 /$ cocv2i1p9

30. Coleman, S. (2002). The borrowing experience of black and Hispanic-owned small firms: Evidence from the 1998 Survey of Small Business Finances. Academy of Entrepreneurship Journal, 8(1), 1-20.

31. Conyon, M. J., \& Peck, S. I. (1998). Board size and corporate performance: Evidence from European countries. The European Journal of Finance, 4(3), 291-304. https://doi.org/10.1080/135184798337317

32. Darko, J., Aribi, Z. A., Uzonwanne, G. C., Eweje, G., \& Eweje, G. (2016). Corporate governance: The impact of director and board structure, ownership structure and corporate control on the performance of listed companies on the Ghana stock exchange. Corporate Governance: The International Journal of Business in Society, 16(2), 259-277. https://doi.org/10.1108/CG-11-2014-0133

33. Corporate Governance: The in-

34. Dechow, P. M., Sloan, R. G., \& Sweeney, A. P. (1996). Causes and consequences of earnings manipulation: An analysis of firms subject to enforcement actions by the SEC*. Contemporary Accounting Research, 13(1), 1-36. https://doi.org/10.1111/j.1911-3846.1996.tb00489.x

35. Denis, D. J., \& Sarin, A. (1999). Ownership and board structures in publicly traded corporations. Journal of Financial Economics, 52(2), 187-223. https://doi.org/10.1016/S0304-405X(99)00008-2

36. Dionne, G. (2013). Handbook of insurance. Berlin, Germany: Springer Science \& Business Media. https://doi.org/ 10.1007/978-1-4614-0155-1

37. Driffield, N., Mahambare, V., \& Pal, S. (2007). How does ownership structure affect capital structure and firm value? Recent evidence from East Asia. Economics of Transition, 15(3), 535-573. https://doi.org/10.1111/j.14680351.2007.00291.x

38. Ehikioya, B. I. (2009). Corporate governance structure and firm performance in developing economies: Evidence from Nigeria. Corporate Governance: The International Journal of Business in Society, 9(3), 231-243. https://doi.org/10.1108/14720700910964307

39. Eisenberg, T., Sundgren, S., \& Wells, M. T. (1998). Larger board size and decreasing firm value in small firms. Journal of Financial Economics, 48(1), 35-54. https://doi.org/10.1016/S0304-405X(98)00003-8

40. Fama, E. F., \& Jensen, M. C. (1983). Agency problems and residual claims. The Journal of Law and Economics, 26(2), 327-349. https://doi.org/10.1086/467038

41. Flannery, M. J., \& Rangan, K. P. (2006). Partial adjustment toward target capital structures. Journal of Financial Economics, 79(3), 469-506. https://doi.org/10.1016/j.jfineco.2005.03.004

42. FMA, (2013). Is KLSE over-valued and how deep is the correction in the coming crash? Retrieved from http://samcheekong.blogspot.com/2013/08/one-chart-says-it-all-on-how-severe-our.html

43. Forbes, D. P., \& Milliken, F. J. (1999). Cognition and corporate governance: Understanding boards of directors as strategic decision-making groups. Academy of Management Review, 24(3), 489-505. https://doi.org/ $10.2307 / 259138$

44. Fosberg, R. H. (2004). Agency problems and debt financing: Leadership structure effects. Corporate Governance: The International Journal of Business in Society, 4(1), 31-38. https://doi.org/10.1108/ 14720700410521943

45. Friend, I., \& Lang, L. H. (1988). An empirical test of the impact of managerial self-interest on corporate capital structure. The Journal of Finance, 43(2), 271-281. https://doi.org/10.1111/j.1540-6261.1988.tb03938.x

46. Gompers, P., Ishii, J., \& Metrick, A. (2003). Corporate governance and equity prices. The Quarterly Journal of Economics, 118(1), 107-156. https://doi.org/10.1162/00335530360535162

47. Graham, J. R., Harvey, C. R., \& Rajgopal, S. (2005). The economic implications of corporate financial reporting. Journal of Accounting and Economics, 40(1-3), 3-73. https://doi.org/10.1016/j.jacceco.2005.01.002

48. Gruber, M. J., and Warner, J. B. (2012). Bankruptcy costs: Some evidence. The Journal of Finance, 32(2), 337-347. https://doi.org/10.1111/j.1540-6261.1977.tb03274.x

49. Guest, P. M. (2009). The impact of board size on firm performance: Evidence from the UK. The European Journal of Finance, 15(4), 385-404. https://doi.org/10.1080/13518470802466121

50. Haniffa, R. M., and Cooke, T. E. (2002). Culture, corporate governance and disclosure in Malaysian corporations. Abacus, 38(3), 317-349. https://doi.org/10.1111/1467-6281.00112

51. Haron, R. (2014), Capital structure inconclusiveness: Evidence from Malaysia, Thailand and Singapore, International Journal of Managerial Finance, 10(1), 23-38. https://doi.org/10.1108/IJMF-03-2012-0025

52. Holderness, C. G. (2009). The myth of diffuse ownership in the United States. Review of Financial Studies, 22(4), 1377-1408. https://doi.org/10.1093/rfs/hhm069

53. Hovey, M., Li, L., and Naughton, T. (2003). The relationship between valuation and ownership of listed firms in China. Corporate Governance: An International Review, 11(2), 112-122. https://doi.org/10.1111/14678683.00012

54. Huang, R., \& Ritter, J. R. (2009). Testing theories of capital structure and estimating the speed of adjustment. Journal of Financial and Quantitative Analysis, 44(2), 237-271. https://doi.org/10.1017/S0022109009090152

55. Hussainey, K., \& Aljifri, K. (2012). Corporate governance mechanisms and capital structure in UAE. Journal of Applied Accounting Research, 13(2), 145-160. https://doi.org/10.1108/09675421211254849 
56. Islam, M. Z., Islam, M. N., Bhattacharjee, S., \& Islam, A. Z. (2010). Agency problem and the role of audit committee: Implications for corporate sector in Bangladesh. International Journal of Economics and Finance, 2(3), 177-188. https://doi.org/10.5539/ijef.v2n3p177

57. Javeed, A., Hassan, M., \& Azeem, M. (2014). Interrelationship among capital structure, corporate governance measures and firm value: Panel study from Pakistan. Pakistan Journal of Commerce and Social Sciences, 8(3), 572-589. Retrieved from https://www.researchgate.net/publication/280598595_Interrelationship_among_ Capital_Structure_Corporate_Governance_Measures_and_Firm_Value_Panel_Study_from_Pakistan

58. Jensen, M. C. (1993). The modern industrial revolution, exit, and the failure of internal control systems. The journal of finance, 48(3), 831-880. https://doi.org/10.1111/j.1540-6261.1993.tb04022.x

59. Jensen, M. C., \& Meckling, W. H. (1976). Theory of the firm: Managerial behavior, agency costs and ownership structure. Journal of financial economics, 3(4), 305-360. https://doi.org/10.1016/0304-405X(76)90026-X

60. Jiraporn, P., Kim, Y. S., \& Davidson, W. N. (2008). Multiple directorships and corporate diversification. Journal of Empirical Finance, 15(3), 418-435. https://doi.org/10.1016/j.jempfin.2007.07.002

61. Kenny, D. (2018, September 15). Moderator variables. Retrieved on February 27, 2019, from http://davidakenny.net/cm/moderation.htm

62. Kim, R. (2011). A study on capital structure and corporate governance (Dissertation). University of Illinois at Urbana-Champaign.Retrieved from https://core.ac.uk/download/pdf/4832441.pdf

63. Kim, Y., Liu, C., \& Rhee, S. G. (2003). The relation of earnings management to firm size. Social Science Research Network.

64. Kirchmaier, T., \& Grant, J. (2005). Corporate ownership structure and performance in Europe. European Management Review, 2(3), 231-245. https://doi.org/10.1057/palgrave.emr.1500043

65. Kisgen, D. J. (2006). Credit ratings and capital structure. The Journal of Finance, 61(3), 1035-1072. https://doi.org/10.1111/j.1540-6261.2006.00866.x

66. Klein, P., Shapiro, D., and Young, J. (2005). Corporate governance, family ownership and firm value: the Canadian evidence. Corporate Governance: An International Review, 13(6), 769-784. https://doi.org/10.1111/j.1467-8683.2005.00469.x

67. Kuo, H. C., Wang, L. H., \& Liu, H. W. (2012). Corporate governance and capital structure: Evidence from Taiwan SMEs. Review of Economics \& Finance, 2(3), 43-58. Retrieved from http://www.bapress.ca/ref/ article.html?id $=485$

68. La Rocca, M. (2007). The influence of corporate governance on the relation between capital structure and value. Corporate Governance: The International Journal of Business in Society, 7(3), 312-325. https://doi.org/ $10.1108 / 14720700710756580$

69. Lawal, B. (2012). Board dynamics and corporate performance: Review of literature, and empirical challenges. International Journal of Economics and Finance, 4(1), 22-35. https://doi.org/10.5539/ijef.v4n1p22

70. Machado, L. K., Prado, J. W., Vieira, K. C., Antonialli, L. M., \& Santos, A. C. (2015). The relevance of the capital structure in firm performance: A multivariate analysis of Brazilian publicly traded companies. Journal of Education and Research in Accounting, 9(4), 384-401. https://doi.org/10.17524/repec.v9i4.1313

71. Makhlouf, M. H., Laili, N. H., Ramli, N. A., Al-Sufy, F., \& Basah, M. Y. (2018). Board of directors, firm performance and the moderating role of family control in Jordan. Academy of Accounting and Financial Studies Journal, 22(5), 1-15. Retrieved from https://doi.org/10.17524/repec.v9i4.1313

72. Masnoon, M., \& Rauf, M. (2013). Impact of corporate governance on capital structure-a study of KSE listed firms. Global Management Journal for Academic and Corporate Studies, 3(1), 94-110. Retrieved from https://papers.ssrn.com/sol3/papers.cfm?abstract_id=2380056

73. Modugu, K. P. (2013). Capital structure decision: An overview. Journal of Finance and Bank Management, 1(1), 14-27. https://doi.org/10.15640/jfbm

74. Morellec, E. and Nikolov, B. \& Schürhoff, N. Corporate governance and capital structure dynamics (AFA 2009 San Francisco Meetings Paper). https://doi.org/10.2139/ssrn.1106164

75. Myers, S. C. (2003). Financing of corporations. Handbook of the Economics of Finance, 1 (pp. 215-253). https://doi.org/10.1016/S1574-0102(03)01008-2

76. Nazir, M. S., Aslam, A., \& Nawaz, M. M. (2012). The impact of CEO duality on capital structure: A case from nonfinancial sector of Pakistan. American Journal of Scientific Research, 56, 5-12.

77. Nelson, M. W., Elliott, J. A., \& Tarpley, R. L. (2002). Evidence from auditors about managers' and auditors' earnings management decisions. The Accounting Review, 77(s-1), 175-202. https://doi.org/ 10.2308/accr.2002.77.s-1.175

78. Omran, M. M., \& Pointon, J. (2009). Capital structure and firm characteristics: an empirical analysis from Egypt. Review of Accounting and Finance, 8(4), 454-474. https://doi.org/10.1108/14757700911006976

79. Pfeffer, J., \& Salancik, G. R. (2003). The external control of organizations: A resource dependence perspective: Stanford University Press. Retrieved from https://www.sup.org/books/title/?id=5889

80. Pour, E. K., \& Lasfer, M. (2013). Why do companies delist voluntarily from the stock market? (Discussion Paper 2013-050). Retrieved from http://epapers.bham.ac.uk/1725/1/2013-05_E_Kashefi_Pour_and_M_Lasfer.pdf

81. Qadorah, A. A., \& Fadzil, F. H. (2018). The relationship between board size and CEO duality and firm performance: Evidence from Jordan. International Journal of Accounting, Finance and Risk Management, 3(3), 16-20. Retrieved from http://www.sciencepublishinggroup.com/journal/paperinfo?journalid=366\&doi= 10.11648/j.ijafrm.20180303.11

82. Quayyoum, S. \& Zoltán, S., (2015). Leverage as a determinant of return on equity whether firm size moderate leverage? Return on equity relationship. Proceedings of International Academic Conferences 2503654. International Institute of Social and Economic Sciences. Retrieved from https://ideas.repec.org/ p/sek/iacpro/2503654.html

83. Raheja, C. G., (2005). Determinants of board size and composition: A theory of corporate boards. Journal of Financial and Quantitative Analysis, 40(2), 283-306. https://doi.org/10.1017/S0022109000002313

84. Rangan, S. (1998). Earnings management and the performance of seasoned equity offerings. Journal of Financial Economics, 50(1), 101-122. https://doi.org/10.1016/S0304-405X(98)00033-6

85. Rehman, M. A. U., Rehman, R. U., \& Raoof, A. (2010). Does corporate governance lead to a change in the capital structure? American Journal of Social and Management Sciences, 1(2), 191-195. https://doi.org/10.5251/ ajsms.2010.1.2.191.195

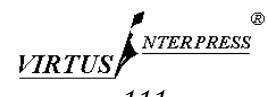


86. Roslan, N. H. (2010). Determinants of financial distress among manufacturing companies in Malaysia (Unpublished Master's thesis, Universiti Utara Malaysia). Retrieved from http://etd.uum.edu.my/ 4924/2/s816217_abstract.pdf.

87. Saad, N. M. (2010). Corporate governance compliance and the effects to capital structure in Malaysia. International Journal of Economics and Finance, 2(1), 105-114. https://doi.org/10.5539/ijef.v2n1p105

88. Savita, T. (2012). A study of capital structure of a firm. Advances in Management, 5(10), 59-68.

89. Sharma, V. D. (2004). Board of director characteristics, institutional ownership, and fraud: Evidence from Australia. Auditing: A Journal of Practice and Theory, 23(2), 105-117. https://doi.org/10.2308/aud.2004.23.2.105

90. Sheikh, N. A., \& Wang, Z. (2012). Effects of corporate governance on capital structure: empirical evidence from Pakistan. Corporate Governance: The international journal of business in society, 12(5), 629-641. https://doi.org/10.1108/14720701211275569

91. Short, H., Keasey, K., \& Duxbury, D. (2002). Capital structure, management ownership and large external shareholders: A UK analysis. International Journal of the Economics of Business, 9(3), 375-399. https://doi.org/10.1080/1357151021000010382

92. Shumway, T. (2001). Forecasting bankruptcy more accurately: A simple hazard model. The Journal of Business, 74(1), 101-124. https://doi.org/10.1086/209665

93. Shumway, T. (2001). Forecasting Bankruptcy More Accurately: A Simple Hazard Model*. The Journal of Business, 74(1), 101-124.

94. Strebulaev, I. A. (2007). Do tests of capital structure theory mean what they say? The Journal of Finance, 62(4), 1747-1787. https://doi.org/10.1111/j.1540-6261.2007.01256.x

95. Sulong, Z., \& Nor, F. M. (2008). Dividends, ownership structure and board governance on firm value: Empirical evidence from Malaysian listed firms. Malaysian Accounting Review, 7(2), 55-94. Retrieved from http://ir.uitm.edu.my/id/eprint/220/

96. Sundaram, R. K., \& Yermack, D. L. (2007). Pay me later: Inside debt and its role in managerial compensation. The journal of finance, 62(4), 1551-1588. https://doi.org/10.1111/j.1540-6261.2007.01251.x

97. Uzun, H., Szewczyk, S. H., \& Varma, R. (2004). Board composition and corporate fraud. Financial Analysts Journal, 60(3), 33-43. https://doi.org/10.2469/faj.v60.n3.2619

98. Vafeas, N. (2000). Board structure and the informativeness of earnings. Journal of Accounting and Public Policy, 19(2), 139-160. https://doi.org/10.1016/S0278-4254(00)00006-5

99. Vo, D., \& Phan, T. (2013). Corporate governance and firm performance: Empirical evidence from Vietnam. Economic Regulation Authority, Perth, Australia. Retrieved from https://www.murdoch.edu.au/School-ofBusiness-and-Governance/_document/Australian-Conference-of-Economists/Corporate-governance-and-firmperformance.pdf

100. Wahba, H. (2015). The joint effect of board characteristics on financial performance: Empirical evidence from Egypt. Review of Accounting and Finance, 14(1), 20-40. https://doi.org/10.1108/RAF-03-2013-0029

101. Wen, Y., Rwegasira, K., \& Bilderbeek, J. (2002). Corporate governance and capital structure decisions of the Chinese listed firms. Corporate Governance: An International Review, 10(2), 75-83. https://doi.org/10.1111/1467-8683.00271 